\title{
Bioassay Guided Fractionation of Marine Streptomyces sp. GMY01 and Antiplasmodial Assay using Microscopic and Flow Cytometry Method
}

\author{
Ema Damayanti1,2*, Jaka Widada ${ }^{3}$, Puspa Dewi N. Lotulung ${ }^{4}$, Achmad Dinoto5 $^{5}$ Mustofa $^{6 *}$
}

1. Study Program for Biotechnology, Graduate School, Universitas Gadjah Mada, Jl. Teknika Utara, Sleman, Yogyakarta, Indonesia, 55281

2. Research Division for Natural Product Technology, Indonesian Institute of Sciences, Jl. Jogja - Wonosari KM 31.5, Gaunungkidul, Yogyakarta, Indonesia, 55861

3. Department of Agricultural Microbiology, Faculty of Agriculture, Universitas Gadjah Mada, Jl. Flora, Bulaksumur, Sleman, Yogyakarta, Indonesia, 55281

4. Research Center for Chemistry, Indonesian Institute of Sciences, Jl. Puspiptek, Serpong, Tangerang Selatan, Banten, Indonesia, 15314

5. Research Center for Biology, Indonesian Institute of Sciences, Jl. Raya Jakarta - Bogor KM 46, Cibinong, Jawa Barat, Indonesia, 16911

6. Department of Pharmacology and Therapy, Faculty of Medicine, Public Health and Nursing, Universitas Gadjah Mada, Jl. Farmako, Sekip Utara, Sleman, Yogyakarta, Indonesia, 55281

\begin{tabular}{|c|c|}
\hline Info Article & ABSTRACT \\
\hline Submitted: $20-10-2020$ & Marine-derived Streptomyces sp. GMY01 is a potential actinobacteria \\
\hline Revised: $10-11-2020$ & which have anticancer activities. In previous studies, several anticancer \\
\hline Accepted: $20-12-2020$ & agents exhibited antiplasmodial activity. This study aimed to evaluate \\
\hline${ }^{*}$ Corresponding author & antiplasmodial activity of GMY01 extract using bioassay guided fractionation. \\
\hline Mustofa & Crude extract of ethyl acetate was obtained from supernatant of 11 days \\
\hline & fermentation in starch nitrate medium. Crude extract was fractionated using \\
\hline \multirow[t]{10}{*}{$\begin{array}{l}\text { Email: } \\
\text { mustofafk@ugm.ac.id }\end{array}$} & $\begin{array}{l}n \text {-hexane and methanol solvent. Re-fractionation was applied using flash } \\
\text { chromatography and column chromatography. Antiplasmodial assay was }\end{array}$ \\
\hline & performed on Plasmodium falciparum FCR3 and P. falciparum 3D7 by \\
\hline & $\begin{array}{l}\text { microscopic method using thin blood smear }+ \text { Giemsa stain, and was } \\
\text { confirmed by flow cytometry method using SYBR Green I stain. Toxicity assay }\end{array}$ \\
\hline & $\begin{array}{l}\text { was performed on Vero cells line (normal cells). Main constituent of active } \\
\text { fraction was analyzed using LCMS/MS. The result of the study showed that }\end{array}$ \\
\hline & ethyl acetate-methanol fraction has high antiplasmodial activity \\
\hline & $\begin{array}{l}(\mathrm{IC} 50=3.96 \mu \mathrm{g} / \mathrm{mL}) \text { with very low toxicity on Vero cells }(\mathrm{IC} 50=30,0 / 2 \mu \mathrm{g} / \mathrm{mL}) \text {. } \\
\text { Bioassay guided fractionation resulted } \mathrm{F} 4.7 \text { which has the highest }\end{array}$ \\
\hline & Plasmodium inhibition $(94.3 \%$ at $5 \mu \mathrm{g} / \mathrm{mL})$. Main constituent analysis showed \\
\hline & $\mathrm{C}_{10} \mathrm{H}_{13} \mathrm{NO}(163.09971 \mathrm{Da})$ and $\mathrm{C}_{11} \mathrm{H}_{15} \mathrm{NO}_{13}(209.10519 \mathrm{Da})$ as two mayor \\
\hline & $\begin{array}{l}\text { compounds in F4.7. This study guided the isolation and structure elucidation } \\
\text { of potential compound in further research. }\end{array}$ \\
\hline & $\begin{array}{l}\text { Key words: Actinomycetes, drug discovery, malaria, antiplasmodial assay, } \\
\text { SYBR Green I }\end{array}$ \\
\hline
\end{tabular}

\section{INTRODUCTION}

Streptomyces as the main sources of new bioactive compounds is used for producing two-thirds of all currently available antibiotics. It has a very large genome size, between 6.2 and 12.7 $\mathrm{Mb}$, and $5 \%$ of its genome is devoted to the synthesis of secondary metabolites (Undabarrena et al., 2017; Weber et al., 2015). In the past ten years, the discovery of new compounds from marine bacteria, especially from the Streptomyces genus, has led to the discovery of new anticancer (Nguyen et al., 2020; Dhaneesha et al., 2019). In the previous study, we discovered the marine bacterium Streptomyces sp. GMY01 (7.9Mbp) which has very high potential for therapeutic agent especially as anticancer (Herdini et al., 2016) . The GMY01 extract shows anticancer activities on T47D and MCF7 breast cancer cell lines (Farida et al., 2007; Werdyani et al., 2017). 
Malaria is a critical disease in humans caused by Plasmodium majority Plasmodium falciparum parasite infection transmitted by the female Anopheles mosquito bite (Vega-Rodríguez et al., 2015). The emergence of drug-resistant Plasmodium drives the efforts of the expert to find and develop new drugs. The discovery of new antimalarial agents from marine actinobacteria is tremendously limited because $72 \%$ of antiplasmodial natural products are still plantsourced (Tajuddeen \& Van Heerden, 2019). New antimalarial drugs could be developed from anticancer compounds. Previous studies have shown that antiplasmodium has a synergetic effect similar to that of anticancer compounds (CrespoOrtiz \& Wei, 2012; Das, 2015). In another study, an anticancer compound inhibited P. falciparum and $P$. berghei (Sumanadasa et al., 2012).

Based on the synergy properties of anticancer and antiplasmodium compounds, we predict that Streptomyces sp. GMY01 also has potential as an antiplasmodium. In this research, we evaluated antiplasmodial activity of Streptomyces sp. GMY01 using bioassay guided fractionation. For antiplasmodial assay, we used microscopic method using thin blood smear with Giemsa stain (Hall \& Fauci, 2009) and flow cytometry method using SYBR Green I nucleic acid dye (Rebelo et al., 2013). To predict active compounds on potential fraction, we conducted main constituent analysis using Liquid Chromatography-Mass Spectrometry/Mass Spectrometry (LCMS/MS).

\section{MATERIAL AND METHODS Biological materials}

Streptomyces sp. strain GMY01 was isolated from a marine sediment sample collected from Krakal Beach (88'44"S 110³5'59"E), Gunungkidul, Yogyakarta Province, Indonesia (Farida et al., 2007). Streptomyces sp. GMY01 was deposited at the Indonesian Culture Collection (WDCM 769), Indonesian Institute of Sciences (LIPI) as InaCC A147 and NITE Biological Research Center (NBRC, WDCM 825) Japan with registration number NBRC 110111. The nucleotide sequence of the 16S rRNA gene was assigned to GenBank accession no. MN922642. Plasmodium falciparum FCR3 and $P$. falciparum 3D7 was obtained from the Eijkman Institute, Jakarta, Indonesia. Vero (ATCCCCL81) cell line were obtained from the Faculty of Medicine, Health Public and Nursing, Universitas Gadjah Mada (UGM), Yogyakarta, Indonesia. In vitro assays for antiplasmodial activity used human blood from adult male donors and was approved by the Medical and Health Research Ethics Committee of the Faculty of Medicine, Public Health and Nursing, UGM (KE/FK/0279/EC/2019).

\section{Fermentation and extraction}

GMY01 bacteria were maintained in International Streptomyces Project-2 (ISP-2) agar medium (Difco, Sparks, USA). GMY01 was cultured at $28^{\circ} \mathrm{C}$ with $180 \mathrm{rpm}$ agitation for 3 days in a $250 \mathrm{~mL}$ Erlenmeyer flask which contains $100 \mathrm{~mL}$ of tryptic soy broth (Difco, Sparks, USA) as the seed medium. For fermentation, the cell culture was transferred into four $1000 \mathrm{~mL}$ flasks which contains $500 \mathrm{~mL}$ of starch nitrate broth (SNB) medium and was incubated for 11 days at $28^{\circ} \mathrm{C}$ with $180 \mathrm{rpm}$ agitation in a shaking incubator (Ghanem et al., 2000). Secondary metabolites were obtained by separating the cell biomass from the liquid using refrigerated centrifugation at $4137 \times g$ at $4^{\circ} \mathrm{C}$ for 15min (Farida et al., 2007). The supernatant was extracted twice with an equal volume of ethyl acetate and evaporated using evaporator machine (Buchi, Switzerland) to obtain the crude extract. The crude ethyl acetate extract was dissolved in methanol and fractionated using an equal volume of $n$-hexane to separate the polar and nonpolar fractions.

\section{Fractionations}

The active fraction was re-fractionated using flash chromatography (Reveleris ${ }^{\mathrm{TM}}$, Buchi, Switzerland) and a C-18 column cartridge with water-acetonitrile as the mobile phase to obtain separated fractions. The ethyl acetate-methanol fraction was dissolved in methanol combined with celite (Merck, Germany), with a fraction: celite ratio of 1: $3(\mathrm{w} / \mathrm{w})$, and dried. Flash chromatography was performed on the water ethyl acetatemethanol fraction based on the procedure manual for dry loading samples. All targeted fractions were weighed and evaluated for antiplasmodial assays. The second re-fractionated was performed with column chromatography method using Si 60

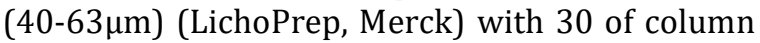
length and $1 \mathrm{~cm}$ of column diameter and methanol: chloroform (4:1) as eluent.

\section{Antiplasmodial assay}

The human parasite $P$. falciparum was cultivated using the Trager and Jensen method with minor modifications (Trager \& Jensen, 2005). Plasmodium was maintained in $2 \%$ human erythrocytes (red blood cells, $\mathrm{RBCs})(\mathrm{O}+$, male) and 
suspended in RPMI 1640 (Gibco, Thermo Fisher Scientific, USA) including $10 \%$ human serum $(0+$, male) and $500 \mu \mathrm{g}$ of gentamicin (Indofarma, Bekasi, Indonesia) per liter. Flask cultures were incubated in a $\mathrm{CO}_{2}$ incubator with $5 \% \mathrm{CO}_{2}$ at $37^{\circ} \mathrm{C}$. Before it was used in treatments, the culture was synchronized with $5 \%$ sorbitol (Lambros \& Vanderberg, 1979) (Mustofa et al., 2007). The sample was prepared by adding $0.1 \%$ dimethyl sulfoxide (DMSO) (Sigma-Aldrich) (w/v) at various concentrations. The Plasmodium growth inhibition assay was performed in a total volume of $200 \mu \mathrm{L}$ using 96-well microplates. Each microplate which contains $100 \mu \mathrm{L}$ of extract solution and $100 \mu \mathrm{L}$ of Plasmodium inoculum at the parasitemia level of $5 \%$ was placed in a $5 \% \mathrm{CO}_{2}$ incubator (CellXpert C170i, Eppendorf AG, Hamburg, Germany) at $37^{\circ} \mathrm{C}$ for $3 \times 24 \mathrm{~h}$. All treatments were performed in triplicate. The Plasmodium growth was investigated by making thin blood film preparations with Giemsa stain and further observed using a microscope (Nikon, Japan). The parasitemia was calculated from a minimum of 1,000 RBCs.

Confirmation of the antiplasmodial assay was carried out by flow cytometer analysis using SYBR Green I stain (Rebelo et al., 2013) with minor modifications. The extract concentration for treatment was $0.25-8 \mu \mathrm{g} / \mathrm{mL}$. For each measurement, $200 \mu \mathrm{L}$ Plasmodium culture (approximately $1.8 \times 10^{11} \mathrm{RBCs}$ ) was centrifuged at $7000 \mathrm{rpm}$ for $10 \mathrm{~min}$ to separate the cells from the medium. Ten microliters of RBC were stained with $2 \mu \mathrm{L}$ DNA-specific dye SYBR Green I (500× the final concentration) (Invitrogen, Carlsbad, USA) and $2 \mu \mathrm{L}$ CD235a antibody (eBioscience, San Diego, USA). After $30 \mathrm{~min}$ of incubation in the dark, the stained sample was washed once by $1 \mathrm{~mL}$ of PBS and centrifuged at $2000 \mathrm{rpm}$ for $5 \mathrm{~min}$. The RBC pellet was collected and dissolved in $400 \mu \mathrm{L}$ flow cytometry buffer (BD) and immediately analyzed by flow cytometry using a $535 / 45 \mathrm{~nm}$ bandpass filter in front of the detector (BD FACSCanto ${ }^{\mathrm{TM}} \mathrm{II}$, USA). The results of flow cytometric analysis were quantitatively analyzed using BD FACSDiva 8.0.2 software. Staining with the anti-glycophorin CD235 antibody was used to establish that all detected events represented RBCs.

The percent Plasmodium inhibition was obtained by formula:

$$
\% \text { inhibition }=\frac{A-B}{A} \times 100
$$

A: The parasitemia or SYBR Green I fluorescens intensity in control (RPMI medium); B: The parasitemia or SYBR Green I fluorescens intensity in treatment

The quantitative data of antiplasmodial assay on microscopic method and flow cytometry method were presented as mean \pm standard deviation (SD) of parasitemia percentage and growth inhibition percentage. One-way ANOVA followed by Dunnett's multiple comparison test for analysis of treatment and two-way ANOVA for analysis of interaction between two methods was done by using GraphPad Prism 8.4.3 software. The half maximal inhibitory concentration $\left(\mathrm{IC}_{50}\right)$ values of the extracts or fraction were determined by nonlinear regression analysis of $\log _{10}$ concentrations of the extract versus percent Plasmodium inhibition which uses GraphPad Prism 8.4.3 software. The interaction between two methods was analyzed by two-way ANOVA.

\section{Toxicity assay}

The 3-(4,5-dimethylthiazol-2-yl)-2,5diphenyl tetrazolium bromide (MTT, SigmaAldrich) assay was employed to evaluate cytotoxicity of the extract on Vero cells as normal cells (Hansen et al., 1989; Hansen et al., 1989). Vero cells were grown in Dulbecco's Modified Eagle Medium-high glucose (Gibco, Thermo Scientific, USA) which were supplemented with $10 \%$ fetal bovine serum (FBS, Gibco, Thermo Scientific, USA). The cells were seeded into a sterile flat bottom 96well microplate (Iwaki) at a density of $5 \times 10^{3}$ cells/well and allowed to adhere overnight at a total volume of $100 \mu \mathrm{L}$ in a humidified incubator $\left(5 \% \mathrm{CO}_{2}, 37^{\circ} \mathrm{C}\right)$. One hundred microliters of extract solution $(0-1000 \mu \mathrm{g} / \mathrm{mL}$ in $0.1 \%$ DMSO) was added to the cells and incubated for $24 \mathrm{~h}$ before performing the MTT assay. Then, $100 \mu \mathrm{L}$ of $5 \mathrm{mg} / \mathrm{mL}$ MTT solution was added to each well, were incubated at $37^{\circ} \mathrm{C}$ in a $\mathrm{CO}_{2}$ incubator for $4 \mathrm{~h}$ and was added by $100 \mathrm{uL}$ sodium dodecyl sulphate (SDS) to stop reaction. The amount of formazan product was determined spectrophotometrically at $595 \mathrm{~nm}$ using a microplate reader (Bio-Rad, California, USA). All treatments were performed in triplicate. Percent cell viability was calculated using the formula:

$$
\% \text { inhibition }=\frac{(A-B)}{A} \times 100
$$

A: the mean absorbance of the control wells; B: the mean absorbance of the treated wells

The $\mathrm{IC}_{50}$ values were determined by nonlinear regression analysis between the $\log _{10}$ concentrations of the extract versus percent cell inhibition using GraphPad Prism 8.4.3 software. 
Table I. Bioactivities of Streptomyces sp. GMY01 fraction using liquid fractionations

\begin{tabular}{lccc}
\hline Fractions & $\begin{array}{c}\text { IC } \mathbf{5 0} \text { P. falciparum FCR3 } \\
(\boldsymbol{\mu g} / \mathbf{m L})\end{array}$ & $\begin{array}{c}\mathbf{I C}_{\mathbf{5 0}} \text { Vero } \\
(\boldsymbol{\mu g} / \mathbf{m L})\end{array}$ & $\begin{array}{c}\text { Selectivity index } \\
(\mathbf{S I})\end{array}$ \\
\hline$n$-hexane-ethyl acetate & Not active & 68.45 & - \\
$n$-hexane free ethyl acetate & 3.83 & 865.3 & 225.9 \\
$n$-hexane-ethyl acetate-methanol & Not active & 57.29 & - \\
Ethyl acetate-methanol & 3.96 & 30,072 & $7,593.94$ \\
Ethyl acetate residual & 6.24 & 52.85 & 8.47 \\
\hline
\end{tabular}
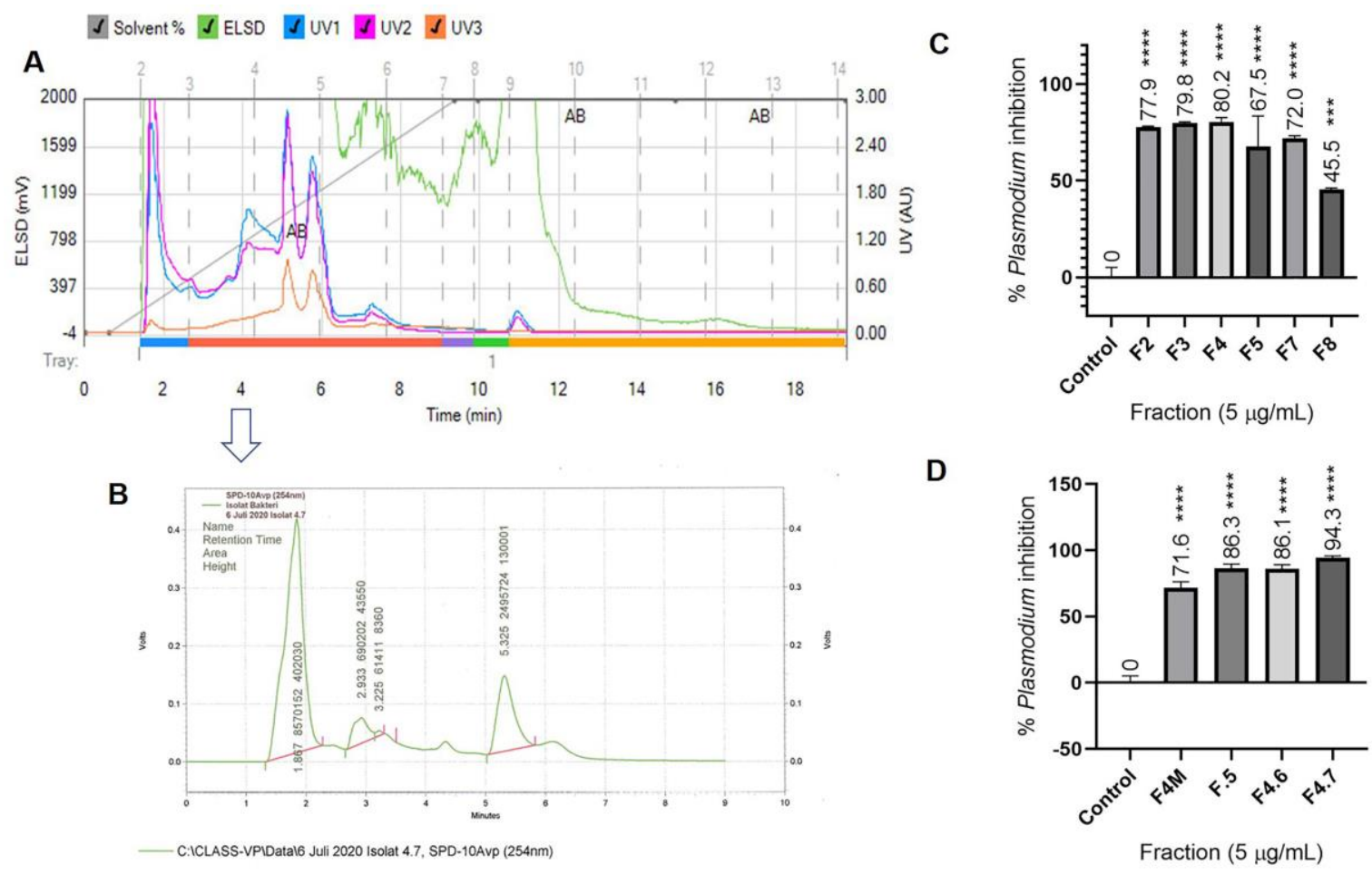

Figure 1. Flash chromatography of ethyl acetate-methanol extract using Reveleris ${ }^{\mathrm{TM}} \mathrm{using} \mathrm{C} 18$ column and eluent water: acetonitrile (A), HPLC profile of fraction 4.7 from column chromatography using Lichoprep Si $60(40-63 \mu \mathrm{m})$ (B), antiplasmodial assay on P. falciparum 3D7 of active fraction from flash chromatography (C) and from column chromatography (D). Value are expressed as mean $\pm \operatorname{SD}\left({ }^{* * *} p<0.001\right.$, $* * * * p 0.0001)$.

The selectivity index (SI) was calculated from the ratio of toxicity on normal cells to antiplasmodial activity (Valdés et al., 2010)

\section{LCMS/MS}

Mass spectrometry analysis was performed on a Xevo G2-XS QTof mass spectrometer (Waters MS Technologies, Milford, USA) (Zhang et al., 2019). Electrospray ionization was adopted. The scan range was from 100 to $1200 \mathrm{~m} / \mathrm{z}$. The capillary and cone voltages were set at $0.8 \mathrm{kV}$ and $30 \mathrm{kV}$, respectively, and positive electron spray mode was adopted. The desolvation gas was set to $1000 \mathrm{~L} / \mathrm{h}$ at a temperature of $500^{\circ} \mathrm{C}$, the cone gas was set to $50 \mathrm{~L} / \mathrm{h}$, and the source temperature was set to $120^{\circ} \mathrm{C}$. Ultra-performance liquid chromatography (UPLC) analysis was performed using a Waters Acquity Ultra Performance LC system. Chromatographic separation was carried out on an ACQUITY UPLC HSS T3 column $(100 \mathrm{~mm} \times 2.1 \mathrm{~mm}$, 1.7 urn) at a column temperature of $40^{\circ} \mathrm{C}$. The mobile phase consisted of solvent A $(0.1 \%$ formic acid in water, $v / v)$ and solvent $B(0.1 \%$ formic acid in acetonitrile), with gradient polarity (A:B) of 
$95: 0.5$ to $0.5: 95$. The flow rate was set at $0.3 \mathrm{~mL} / \mathrm{min}$. The column and auto-sampler were maintained at $40^{\circ} \mathrm{C}$ and $20^{\circ} \mathrm{C}$, respectively. The injection volume was $1 \mathrm{uL}$. The data acquisition and processing were performed using UNIFI. The parameter used was retention time (RT) in the range of $1-16 \mathrm{~min}$.

\section{RESULT AND DISCUSSION}

From the $10 \mathrm{~L}$ supernatant of 11-days old GMY01 cultured in liquid SNB medium, 792mg crude ethyl acetate extract was obtained. Fractionation of the crude ethyl acetate produced $322 \mathrm{mg}$ of $n$-hexane fraction, $37 \mathrm{mg}$ of ethyl acetatemethanol- $n$-hexane fraction, $378 \mathrm{mg}$ of ethyl acetate-methanol fraction, and $7 \mathrm{mg}$ of insoluble fraction. The antiplasmodial activity and toxicity on normal cells of fractions (Table I). $N$-hexane fraction has no effect on Plasmodium and has high toxicity on normal cells. $N$-hexane free ethyl acetate, ethyl acetate-methanol and ethyl acetate residual have similar activities on Plasmodium but own different toxicity on normal cells. The antiplasmodium activity criteria in $P$. falciparum from extracts of natural product are categorized as inactive if they have $\mathrm{IC}_{50}>100 \mu \mathrm{g} / \mathrm{mL}$ while the extracts with $\mathrm{IC}_{50}<100 \mu \mathrm{g} / \mathrm{mL}$ are classified as follows: low active if $\mathrm{SI}<4$, partially active if SI 4-10 and active SI>10 (Valdés et al., 2010). N-hexane free ethyl acetate, ethyl acetate-methanol and ethyl acetate residual have SI $>10$ but ethyl acetatemethanol fraction has the highest SI $(7,593.94)$. This fraction selected for further fractionations.

Flash chromatography result on ethyl acetate-methanol fractionation (Figure 1.A). From 2-6min of running time shows high peak detected on 254, 280 and $366 \mathrm{~nm}$ of UV wavelength. On bioassay of ten fractions shows that F2, F3, F4, and F7 have high antiplasmodial activities (>70\%). All treatment except F8 have significant difference than control $(\mathrm{p}<0.0001)$ (Figure 1.C). Among all fractions, F4 has the highest antiplasmodial activity and has been selected for further fractionations. In further separation procedures by manual column chromatography using silica 60 , we obtained ten fractions. From bioassay on Plasmodium, F4.5, F4.6 and F4.7 have high antiplasmodial activities $(>80 \%)$ and have significant difference than control $(p<0.0001)$ (Figure 1.D). Other fractions which have no effect on Plasmodium were not displayed on this report. F4.7 resulted high antiplasmodial activity (94.3\%) at $5 \mu \mathrm{g} / \mathrm{mL}$ of concentration. The purity analysis using HPLC (C18 column, water: acetonitrile (1:1), isocratic) showed that fraction 4.7 has single mayor compounds and two minor compounds (Figure 1.B).

The antiplasmodial activity of active F4.7 using microscopic methods was confirmed with flow cytometry method. On microscopic analysis, infected RBC on RPMI control medium show schizont stage P. falciparum 3D7 similar with DMSO $0.1 \%$ as sample solution (Figure 2.B1-B2). The Plasmodium still on ring stage like stage on initial assay (0h) (Figure 2.B3). This indicated that Plasmodium growth inhibited by $25 \mu \mathrm{g} / \mathrm{mL}$ of F4.7 fraction treatment. The same results were shown in other studies using $100 \mathrm{ng} / \mathrm{mL}$ of eurycomanone with an incubation time of $72 \mathrm{~h}$ which produced 90\% inhibition with Plasmodium which was discovered to be dominant in the ring and throphozoites stage (Sholikhah et al., 2016). It indicates that based on microscopic assay, F4.7 has high inhibition on Plasmodium. This fact was supported by flow cytometry analysis using SYBR Green I stain.

There was different fluorescens intensity of SYBR Green I on P2 area. P2 area represented the red blood cells (RBC) that infected by Plasmodium (positive SYBR Green I). The high intensity of SYBR Green I indicated the high Plasmodium DNA or the high parasitemia (Figure 2.A1-A2). The low intensity of SYBR Green I was detected on $25 \mu \mathrm{g} / \mathrm{mL}$ F4.7 treatment (Figure 2.A3). Based on parasitemia value, there was difference between microscopic and flow cytometry assay (Figure 2.C). On microscopic assay, schizont stage having multi nuclei was counted as one parasite. Meanwhile, on flow cytometry assay, intensity of SYBR Green I depends on number of Plasmodium DNA on RBC. Multi nuclei stage on Plasmodium infected RBC detected as high intensity. Percentage of inhibition on microscopic assay was higher than flow cytometry assay (Figure 2.D). Nevertheless, both in microscopic and flow cytometry assay, $25 \mu \mathrm{g} / \mathrm{mL}$ of F4.7 treatment has higher inhibition than RPMI and DMSO 0.1\%.

Statistical analysis showed that there was significant interaction of parasitemia percentage $(p<0.0001)$ and Plasmodium inhibition percentage $(p=0.0003)$ between microscopic and flow cytometry method (Table II). The two methods have their own objectives, advantages, and limitations. Thin blood films are preferred to examine the morphology of parasites and to determine species (Bejon et al., 2006) and the staging of Plasmodium (Sholikhah et al., 2016). 

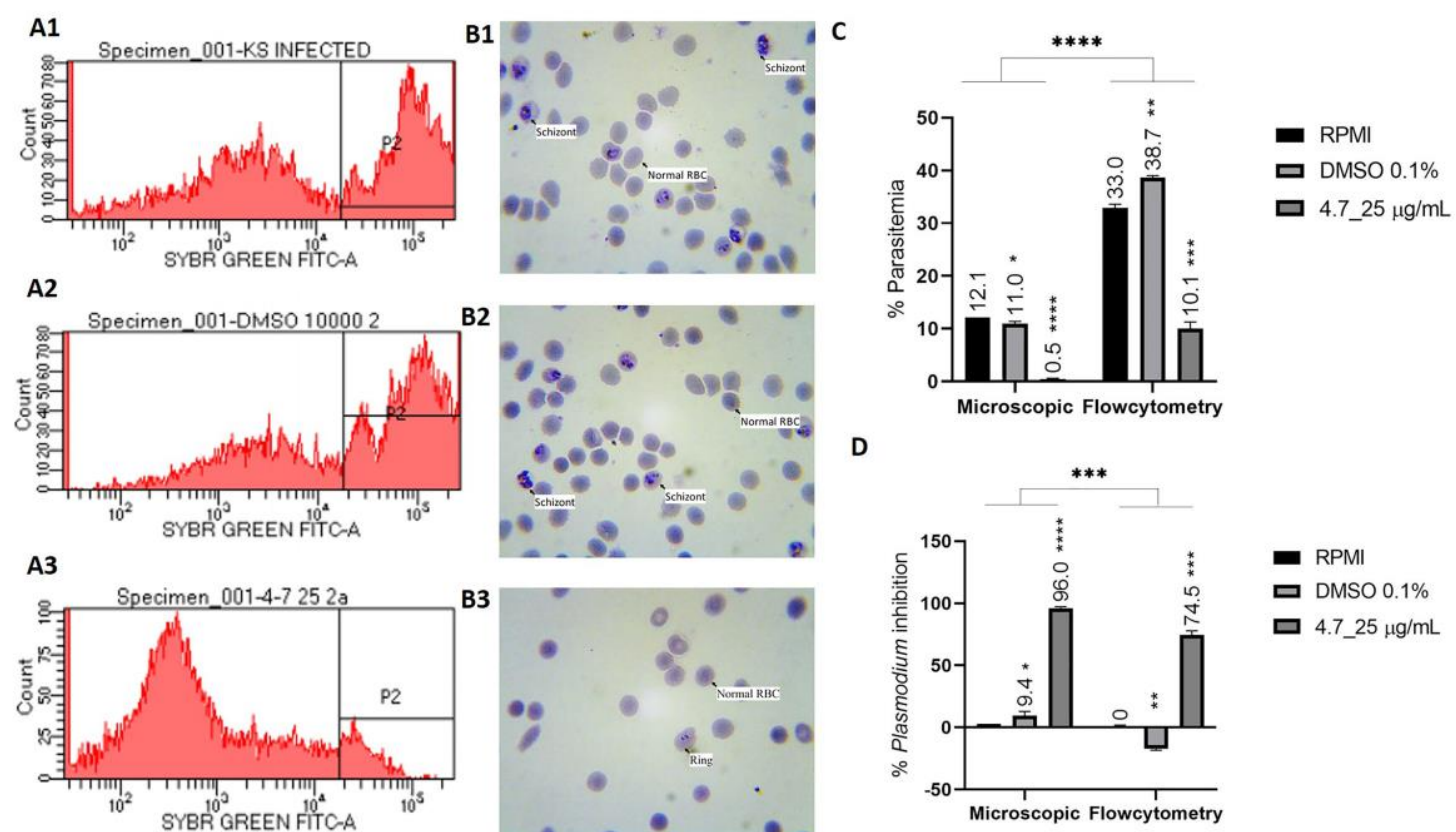

Figure 2. Fluorescens intensity of SYBR Green I on flow cytometry assay (A), parasitemia of Plasmodium falciparum 3D7 on microscopic assay (B). 1: Infected red blood cells (RBC) on RPMI medium (control), 2: Infected RBC on RPMI medium+ 0.1\% DMSO, 3: Infected RBC on $25 \mu \mathrm{g} / \mathrm{mL}$ of F4.7 GMY01. Percentage of parasitemia (C) and percentage of Plasmodium inhibition (D) on antiplasmodial activities of F4.7 using microscopic and flow cytometry method. Value are expressed as mean $\pm \operatorname{SD}\left({ }^{*} p<0.05,{ }^{* *} p<0.01,{ }^{* * *} p<0.001\right.$, $* * * * p<0.0001)$.

Table II. Statistical analysis of interaction between two methods on antiplasmodial assay

\begin{tabular}{ccccccc}
\hline Methods & RMPI & DMSO 0.1\% & F4.7 $(25 \mu \mathrm{g} / \mathbf{m L})$ & Mean & Diff * & $\boldsymbol{p}$ value ** \\
\hline \multicolumn{7}{c}{ \% parasitemia } \\
\hline Microscopic & $12.10 \pm 0.014$ & $10.96 \pm 0.424$ & $0.48 \pm 0.139$ & 7.849 & -19.37 & $<0.0001$ \\
Flow cytometry & $32.95 \pm 0.636$ & $38.65 \pm 0.354$ & $10.05 \pm 1.202$ & 27.22 & \\
\hline \multicolumn{7}{c}{ \% Plasmodium inhibition } \\
\hline Microscopic & $5 \times 10^{-5} \pm 0.118$ & $9.39 \pm 3.503$ & $96.03 \pm 1.145$ & 35.14 & 16.07 & 0.0003 \\
Flow cytometry & $0.00 \pm 1.923$ & $-17.29 \pm 1.068$ & $74.50 \pm 3.43$ & 19.071 & \\
\hline
\end{tabular}

Diff*: Difference between means; $p$ value**: interaction between two methods.

Table III. Detected compounds of fraction 4.7 using LCMS/MS analysis

\begin{tabular}{lccccc}
\hline Compounds & $\begin{array}{c}\text { Retention times } \\
\text { (min) }\end{array}$ & $\begin{array}{c}\text { Observed } \\
\mathbf{m} / \mathbf{z}\end{array}$ & $\begin{array}{c}\text { Neutral mass } \\
\text { (Da) }\end{array}$ & $\begin{array}{c}\text { Adducts } \\
\text { Mass error } \\
\text { (mDa) }\end{array}$ \\
\hline Ephedrine $\left(\mathrm{C}_{10} \mathrm{H}_{15} \mathrm{NO}\right)$ & 4.95 & 166.1220 & 165.11536 & $+\mathrm{H}$ & -0.6 \\
$\mathrm{C}_{10} \mathrm{H}_{13} \mathrm{NO}$ & 5.19 & 164.1064 & 163.09971 & $+\mathrm{H}$ & -0.6 \\
$\mathrm{C}_{11} \mathrm{H}_{15} \mathrm{NO}_{3}$ & 5.54 & 210.1120 & 209.10519 & $+\mathrm{H}$ & -0.4 \\
$\mathrm{C}_{26} \mathrm{H}_{22} \mathrm{O}_{4}$ & 6.16 & 421.1391 & 398.15181 & $+\mathrm{Na}$ & -0.2 \\
$\mathrm{C}_{23} \mathrm{H}_{22} \mathrm{~N}_{2} \mathrm{O}_{7}$ & 6.46 & 439.1494 & 438.14270 & $+\mathrm{H}$ & -0.5 \\
\hline
\end{tabular}


A Item name: Blanko

Channel name: 1: TOF MS ${ }^{£}$ (50-1200) 6eV ESI+ - Low CE (BPI)

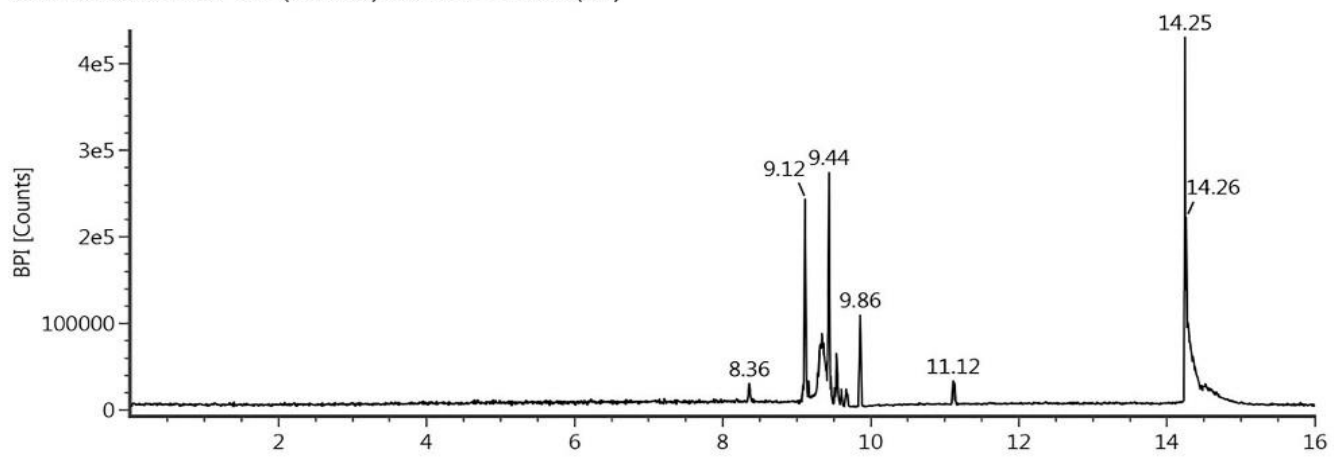

Item name: $200728-1283$

Channel name: 1: TOF MS ${ }^{\mathrm{E}}$ (50-1200) 6eV ESI+ - Low CE (BPI)

B

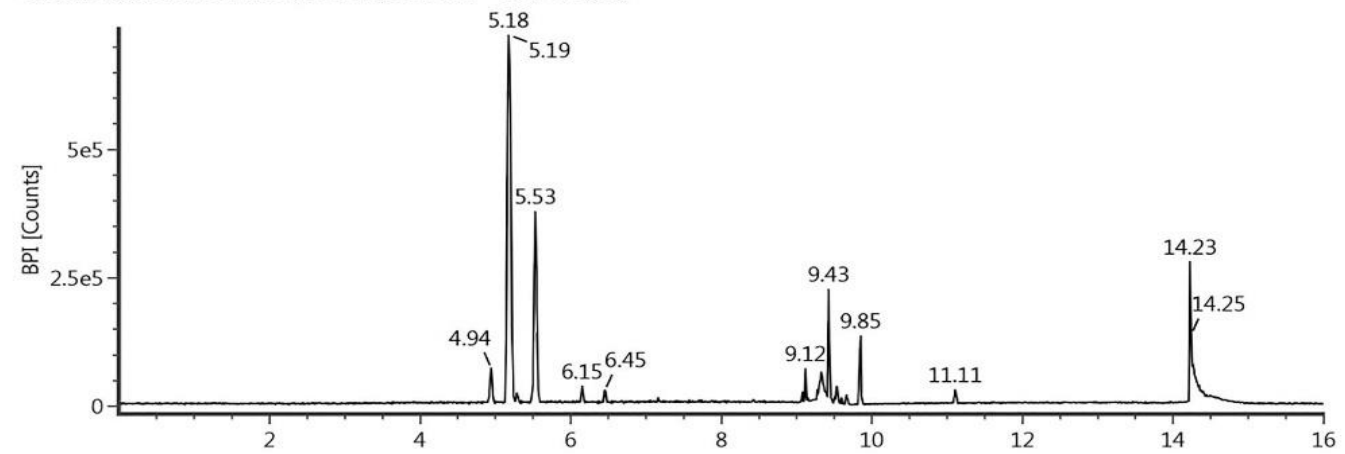

Figure 3. Chromatogram of blank (A) and F4.7 GMY01 (B) using LCMS/MS analysis

Microscopic method using thin blood smear with Giemsa stain is a standard method for observation (Hall \& Fauci, 2009). Flow cytometry techniques are considered simple, fast and valid for monitoring Plasmodium growth (Fong \& Wright, 2013). This method was most widely used in assays for $P$. falciparum in vitro and in vivo (Aguiar et al., 2012). The concentration of antiplasmodial drug inhibition is considered to be more precisely determined by measuring the fluorescent DNA binding dye based on the fact that the host, red blood cells, lacks of DNA (Machado et al., 2016).

Main constituent chromatogram of F4.7 by LCMS/MS analysis (Figure 3). Blank sample chromatogram (Figure 3.A) and F4.7 chromatogram (Figure 3.B). The peak after $8 \mathrm{~min}$ of retention times (RT) was shown as blank peak. There were five compounds detected on F4.7 at 4.9-6.4 min of RT (Table III).

The candidate identified compound with $\mathrm{C}_{10} \mathrm{H}_{13} \mathrm{NO}$ formula at $5.19 \mathrm{~min}$ of RT was mayor compound on F4.7. The second mayor compound $\left(\mathrm{C}_{11} \mathrm{H}_{15} \mathrm{NO}_{3}\right)$ was identified at $5.54 \mathrm{~min}$ of RT. The mayor compound in $\mathrm{F} 4.7$ predicted as isobutyranilide which has $\mathrm{C}_{10} \mathrm{H}_{13} \mathrm{NO}$ formula and $163.099714 \mathrm{~g} / \mathrm{mol}$ of exact mass (available on https://pubchem.ncbi.nlm.nih.gov/compound/Iso butyranilide, accessed on 9 November 2020). Based on bioassay study, this compound was inactive as anticancer assay. The second mayor compound was predicted as propoxur (2isopropoxyphenyl-methylcarbamate) which has $\mathrm{C}_{11} \mathrm{H}_{15} \mathrm{NO}_{3}$ formula and $209.105193 \mathrm{~g} / \mathrm{mol}$ of exact mass. This compound was known to have activity as an insecticide (available on https://pubchem.ncbi.nlm.nih.gov/compound/49 44, accessed on 9 November 2020). Another compound was predicted as ephedrine which has $\mathrm{C}_{10} \mathrm{H}_{15} \mathrm{NO}$ formula and $165.115364 \mathrm{~g} / \mathrm{mol}$ of exact mass (available on https://pubchem.ncbi.nlm.nih.gov/compound/92 94, accessed 9 November 2020). Ephedrine is an alkaloid compound with potential bronchodilator and anti-hypotensive activity. Isolation and elucidation procedures of single compound are needed to conduct in further study. This effort 
guided to obtain an active compound which is responsible as antiplasmodial compound.

\section{CONCLUSION}

The fractionation method which uses liquid fractionation, flash chromatography and column chromatography can be used in screening antiplasmodial candidates from bacteria. Our result show ethyl acetate-methanol fraction has high antiplasmodial activity with very low toxicity on Vero cells. Bioassay guided fractionation resulted F4.7 as the highest Plasmodium inhibition and was confirmed by microscopic and flow cytometry assay. The main constituent analysis showed $\mathrm{C}_{10} \mathrm{H}_{13} \mathrm{NO}(163.09971 \mathrm{Da})$ and $\mathrm{C}_{11} \mathrm{H}_{15} \mathrm{NO}_{13}$ (209.10519 Da) two as mayor compound.

\section{ACKNOWLEDGEMENT}

This research was funded by Indonesian Ministry of Higher Education (grant number: 2784/UN1.P.III/DIT-LIT/LT/2019) awarded to M. Authors thank to Indonesian Ministry of Research and Technology for scholarship awarded to ED. Authors also thank to Khoirun Nisa, Ph.D and Ahmad Sofyan, Ph.D for technical assistance in fractionation procedures and statistical analysis.

\section{REFERENCES}

Aguiar, A. C. C., da Rocha, E. M. M., de Souza, N. B., França, T. C. C., \& Krettli, A. U. (2012). New approaches in antimalarial drug discovery and development - A Review. Memorias Do Instituto Oswaldo Cruz, 107(7), 831-845. https://doi.org/10.1590/S007402762012000700001

Bejon, P., Andrews, L., Hunt-Cooke, A., Sanderson, F., Gilbert, S. C., \& Hill, A. V. S. (2006). Thick blood film examination for Plasmodium falciparum malaria has reduced sensitivity and underestimates parasite density. Malaria Journal, 5, 5-8. https://doi.org/10.1186/1475-2875-5-104

Crespo-Ortiz, M. P., \& Wei, M. Q. (2012). Antitumor activity of artemisinin and its derivatives: From a well-known antimalarial agent to a potential anticancer drug. Journal of Biomedicine and Biotechnology, 2012. https://doi.org/10.1155/2012/247597

Das, A. (2015). Anticancer effect of antimalarial artemisinin compounds. Annals of Medical and Health Sciences Research. https://doi.org/10.4103/21419248.153609

Dhaneesha, M., Hasin, O., Sivakumar, K. C.,
Ravinesh, R., Naman, C. B., Carmeli, S., \& Sajeevan, T. P. (2019). DNA Binding and Molecular Dynamic Studies of Polycyclic Tetramate Macrolactams (PTM) with Potential Anticancer Activity Isolated from a Sponge-Associated Streptomyces zhaozhouensis subsp. mycale subsp. nov. Marine Biotechnology. https://doi.org/10.1007/s10126-0189866-9

Farida, Y., Widada, J., \& Meiyanto, E. (2007). Combination Methods for Screening Marine Actinomycetes Producing Potential Compounds as Anticancer. Indonesian Journal of Biotechnology, 12(2), 988-997. https://doi.org/10.22146/ijbiotech.7772

Fong, K. Y., \& Wright, D. W. (2013). Hemozoin and antimalarial drug discovery. Future Medicinal Chemistry, 5(12), 1437-1450. https://doi.org/10.4155/fmc.13.113

Ghanem, N. B., Sabry, S. A., El-Sherif, Z. M., \& Abu ElEla, G. A. (2000). Isolation and enumeration of marine actinomycetes from seawater and sediments in Alexandria. Journal of General and Applied Microbiology, 46(3), 105-111. https://doi.org/10.2323/jgam.46.105

Hall, B. F., \& Fauci, A. S. (2009). Malaria control, elimination, and eradication: The role of the evolving biomedical research agenda. Journal of Infectious Diseases, 200(11), 1639-1643. https://doi.org/10.1086/646611

Hansen, M. B., Nielsen, S. E., \& Berg, K. (1989). Reexamination and further development of a precise and rapid dye method for measuring cell growth/cell kill. Journal of Immunological Methods. https://doi.org/10.1016/00221759(89)90397-9

Herdini, C., Hartanto, S., Mubarika, S., Hariwiyanto, B., Wijayanti, N., Hosoyama, A., Yamazoe, A., Nojiri, H., \& Widada, J. (2016). Diversity of Nonribosomal Peptide Synthetase Genes in the AnticancerProducing Actinomycetes Isolated from Marine Sediment in Indonesia. Indonesian Journal of Biotechnology, 20(1), 34. https://doi.org/10.22146/ijbiotech.15266

Lambros, C., \& Vanderberg, J. P. (1979). Synchronization of Plasmodium falciparum erythrocytic stages in culture. Journal of Parasitology. https://doi.org/10.2307/3280287

Machado, M., Murtinheira, F., Lobo, E., \& Nogueira, 
F. (2016). Whole-Cell SYBR Green I Assay for Antimalarial Activity Assessment. Ann Clin Med Microbio, 2(1), 1010. https://www.jscimedcentral.com/Medical Microbiology/medicalmicrobiology-21010.pdf

Mustofa, Sholikhah, E. N., \& Wahyuono, S. (2007). In vitro and in vivo antiplasmodial activity and cytotoxicity of extracts of Phyllanthus niruri L. herbs traditionally used to treat malaria in Indonesia. Southeast Asian Journal of Tropical Medicine and Public Health, 38(4), 609-615.

Nguyen, H. T., Pokhrel, A. R., Nguyen, C. T., Pham, V. T. T., Dhakal, D., Lim, H. N., Jung, H. J., Kim, T. S., Yamaguchi, T., \& Sohng, J. K. (2020). Streptomyces sp. VN1, a producer of diverse metabolites including non-natural furantype anticancer compound. Scientific Reports. https://doi.org/10.1038/s41598020-58623-1

Rebelo, M., Sousa, C., Shapiro, H. M., Mota, M. M., Grobusch, M. P., \& Hänscheid, T. (2013). A Novel Flow Cytometric Hemozoin Detection Assay for Real-Time Sensitivity Testing of Plasmodium falciparum. PLoS ONE. https://doi.org/10.1371/journal.pone.0061 606

Sholikhah, E. N., Wijayanti, M. A., Susidarti, R. A., Purwantini, I., Hestiyani, R. A. N., Yusuf, H., \& Mustofa. (2016). Stage specificity of eurycomanone isolated from Eurycoma longifolia on Plasmodium falciparum cycles. American Journal of Pharmacology and Toxicology, 11(1), 1-7. https://doi.org/10.3844/ajptsp.2016.1.7

Sumanadasa, S. D. M., Goodman, C. D., Lucke, A. J., Skinner-Adams, T., Saham, I., Haque, A., Do, T. A., McFadden, G. I., Fairlie, D. P., \& Andrews, K. T. (2012). Antimalarial activity of the anticancer histone deacetylase inhibitor SB939. Antimicrobial Agents and Chemotherapy, 56(7), 3849-3856. https://doi.org/10.1128/AAC.00030-12

Tajuddeen, N., \& Van Heerden, F. R. (2019). Antiplasmodial natural products: An update. Malaria Journal, 18(1), 1-62. https://doi.org/10.1186/s12936-0193026-1

Trager, W., \& Jensen, J. B. (2005). Human malaria parasites in continuous culture. Journal of Parasitology. https://doi.org/10.1645/00223395(2005)091[0484:HMPICC]2.0.CO;2

Undabarrena, A., Ugalde, J. A., Seeger, M., \& Cámara, B. (2017). Genomic data mining of the marine actinobacteria Streptomyces sp. HKF8 unveils insights into multi-stress related genes and metabolic pathways involved in antimicrobial synthesis. PeerJ, 2017(2). https://doi.org/10.7717/peerj.2912

Valdés, A. F. C., Martínez, J. M., Lizama, R. S., Gaitén, Y. G., Rodríguez, D. A., \& Payrol, J. A. (2010). Actividad antimalárica in vitro $\mathrm{y}$ citotoxicidad de algunas plantas medicinales Cubanas seleccionadas. Revista Do Instituto de Medicina Tropical de Sao Paulo, 52(4), 197-201. https://doi.org/10.1590/S003646652010000400006

Vega-Rodríguez, J., Pastrana-Mena, R., CrespoLladó, K. N., Ortiz, J., Ferrer-Rodríguez, I., \& Serrano, A. E. (2015). Implications of glutathione levels in the plasmodium berghei response to chloroquine and artemisinin. PLoS ONE, 10(5), 1-15. https://doi.org/10.1371/journal.pone.0128 212

Weber, T., Charusanti, P., Musiol-Kroll, E. M., Jiang, X., Tong, Y., Kim, H. U., \& Lee, S. Y. (2015). Metabolic engineering of antibiotic factories: New tools for antibiotic production in actinomycetes. Trends in Biotechnology, 33(1), 15-26. https://doi.org/10.1016/j.tibtech.2014.10. 009

Werdyani, S., Wijayanti, N., Fitria, A., \& Rahmawati, S. (2017). Cytotoxic effects of ethyl acetate fractions from secondary metabolites of Streptomyces Sp. GMY01 on human breast cancer MCF7 cell lines. Asian Journal of Pharmaceutical and Clinical Research, 10(Special Issue August), 9-11. https://doi.org/10.22159/ajpcr.2017v10s3 .21351

Zhang, L., Wang, J., Li, T., Li, P., Wang, Y., Yang, M., Liu, J., \& Liu, J. (2019). Determination of the chemical components and phospholipids of velvet antler using UPLC/QTOF-MS coupled with UNIFI software. Experimental and Therapeutic Medicine, 3789-3799. https://doi.org/10.3892/etm.2019.7372 